\title{
磁場の実験的解析に基づく磁気ナビゲーション法の実装
}

\author{
赤 井 直 紀*1 Sam Ann Rahok*2 片 寄 浩 平*1 \\ 島田遼*1 井上一道*1 尾 崎功一*1
}

\section{Implementation of Magnetic Navigation Method based on Experimental Analysis of Magnetic Field}

\author{
Naoki Akai*1, Sam Ann Rahok*2, Kohei Katayose*1, \\ Ryo Shimada*1 $^{* 1}$ Kazumichi Inoue*1 and Koichi Ozaki*1
}

\begin{abstract}
In practical use of automatic guided vehicles, magnetic markers are widely used. However, an approach of which pattern of magnetic intensity in usual environment is defined as landmarks is not investigated. This reason is that it is difficult to be known environmental magnetic field since magnetic intensity is invisible. This paper shows investigation of environmental magnetic field in actual environment and describes implementation of the magnetic based navigation, magnetic navigation method. As the magnetic investigation, magnetic intensity of the mounted devices in a mobile robot was measured, and condition of efficient layout of the devices was obtained. By the measurement of environmental magnetic field in mentioned condition, pattern of magnetic intensity that is suitable as a landmark is shown in this paper. The mobile robot records magnetic intensity on its travel path as magnetic map, and achieves stable navigation based on the magnetic map. In this paper, performance of the magnetic navigation method is shown by an experiment.
\end{abstract}

Key Words: Environmental Magnetic Field, Magnetic Navigation Method, Mobile Robot and Analysis

\section{1.は じめに}

実用稼働している無人搬送車の多くは，経路上に設置された 磁場の目印をトレースすることで安定した走行を実現している. このように，ロボットが安定した自律走行を行うために磁場を 利用することは有力であるが，目印設置等の経路設定にかかる コストが高い $[1]$ ，そこで筆者らは，環境中にそのまま存在する 磁場（以下「環境磁場」）を利用した走行法（磁気ナビゲーショ ン法：Magnetic Navigation Method [2] [3]）を提案してきた. 磁場方位のように，環境磁場の利用は古くからある考え方で あり, 一見容易なように感じられるかもしれない. しかし, 地 上，特に建物などの人工物に囲まれた環境では，磁性体による 地磁気の乱れが多々存在するため, 安定した方位を得ることは 困難である。これまで渡辺らやWoong らは, 磁場方位を利用 してロボットの姿勢を推定する方法を提案してきた $[4][5]$. これ らの論文では, 磁場の乱れる場所の存在を指摘しながらも, 他 のセンサを利用するなど, 磁場の乱れをいかに回避するかを課

原稿受付 2012 年 12 月 10 日

*1宇都宮大学

$* 2$ 小山工業高等専門学校

${ }^{* 1}$ Utsunomiya University

${ }^{* 2}$ Oyama National College of Technology
題としている。これに対し筆者らが提案している磁気ナビゲー ション法は, 磁場の乱れを回避するのではなく，それを目印と した位置推定を行うことを特徵とした自律走行法である。これ まで著者らは, 磁気ナビゲーション法によってつくばチャレン ジでの課題である $1[\mathrm{~km}]$ を越える自律走行を達成してきた.

しかし磁気ナビゲーション法は, GPS や LIDAR (Light Detection and Ranging) を用いたナビゲーション法 [6] [7] と比べ 応用事例が少ない. これは, 磁場が不可視であり直感的に把握 できないことが理由と考えられる，著者ら自身も，環境磁場の 把握については経験的なところが多く, 磁気ナビゲーション法 が容易に利用できる技術ではないと考えている。ささらに問題と なるのは，ロボットに搭載される電子機器が磁性体となること である，当然ながらこのことは，周囲の磁場に影響を及ぼすた め, 磁気ナビゲーション法に対しても影響を与えることとなる.

そこで本論文では，ロボットに搭載される電子機器および環 境磁場を実験的に解析することで，それらがどのような性質を 持つかを調査することとした。そして，この調査結果に基づい て磁気ナビゲーション法の実装を行い，実際に評価実験を行う ことで本手法の有用性を考察することとした.

本論文の構成は以下のとおりである。まず 2 章では, 磁気ナ ビゲーション法の概念について述べる. 3 章では, ロボットに 搭載される電子機器や環境磁場について実験的に解析すること 
でその性質を明らかにする，4章では，3 章の結果に基づいて 磁気ナビゲーション法の実装を行う，5章では，実装した磁気 ナビゲーション法を用いて走行実験を行い, 本手法の有用性を 考察する. 6 章において本研究をまとめる.

\section{2. 磁気ナビゲーション法の概念}

\section{1 環境磁場を用いたナビゲーション法}

文献 [4] [5] で提案されているように, 磁場の乱れがない地点 において，磁場方位を用いた姿勢推定を行うことは有用である. しかし実際の環境では, 鉄骨などの磁性体が磁場を乱す区間が 存在するため, 姿勢推定を行うことが難しい区間も存在する. 著者らが提案している磁気ナビゲーション法では, このような 磁場の乱れを利用して位置推定を行う。また，それ以外の磁場 の安定している地点では，文献 [4] [5] で提案されているように， 磁場方位を用いた姿勢修正を行う。これらは周囲の動的障害物 （磁性体を除く）から影響を受けないため, 磁気ナビゲーション 法は様々な環境で利用することができる。

Fig. 1 は，磁場の乱れを用いた位置推定法の概念図である。 鉄骨などの磁性体は，残留磁場と呼ばれる磁場を生成する [8] 残留磁場は磁性体により生成されるため, 強さが場所ごとに変 化し，時間的には安定するという性質を持つ。筆者らが提案し ている磁気ナビゲーション法では, オドメトリによる位置推定 の累積誤差を磁場の乱れを利用して修正している.

残留磁場を利用した位置推定法では，次の二つの方法をとる ことができる。（1）環境磁場を空間地図として取得しこれを利 用する方法，（2）ロボットの経路上およびその周辺の磁場のみ を利用する方法である。広い範囲を移動するロボットにとって は（1）の方法が望ましいが，環境磁場すべてを計測して地図化 するのは手間のかかる作業である。一方（2）の方法では，位置 推定は指定した経路周辺のみに限られてしまうが，移動する経 路を特定することができれば，（2）の方法でも十分である.

\section{2 磁場マップ}

本稿では，(2) の方法による磁気ナビゲーション法について 述べる。なお（1）の手法の詳細は文献 [9] に讓る.

ロボットの経路は, 移動距離および姿勢からトポロジィ的に 表現することができる。この経路情報に基づいて環境磁場情報 $\boldsymbol{M}=\left[\boldsymbol{M}_{b, 0}, \boldsymbol{M}_{b, 1}, \ldots, \boldsymbol{M}_{b, N}, \boldsymbol{M}_{\theta, 0}, \boldsymbol{M}_{\theta, 1}, \ldots, \boldsymbol{M}_{\theta, N}\right]$ を記録 することで，経路周辺の磁場について知ることができる．ここで， $N$ は磁場デー夕を記録した地点（ノード）の数であり， $M_{b}$ は磁 場強度， $\boldsymbol{M}_{\theta}$ は磁場方位をそれぞれ表す. 便宜上, $\boldsymbol{M}_{n}=\left[\boldsymbol{M}_{b, n}\right.$, $\left.M_{\theta, n}\right]$ とする. 本研究では, 経路情報に基づいて環境磁場を記 録したものを「磁場マップ」と定義する.

Fig. 2 は，磁場マップの実装例である，距離ごとに磁場強度 $M_{b, n}$ が記録されていることによって，ロボットは経路上の磁 場の変化を識別することができる。また，磁場強度を用いれば 磁場方位 $M_{\theta, n}$ を計算することができる，磁場方位を用いるこ とで，ロボット自身の姿勢を利用しなくともトポロジィな地図 表現を行える。ささらに付加情報として，各ノードに環境磁場の 性質を記録する。これには，磁場の乱れのパターンを識別する ための識別情報 $\boldsymbol{S}_{n}$ と, 磁場を制御に利用する量を調整する重 み情報 $\boldsymbol{W}_{n}$ の 2 種類を用いる。これらを利用して経路周辺の

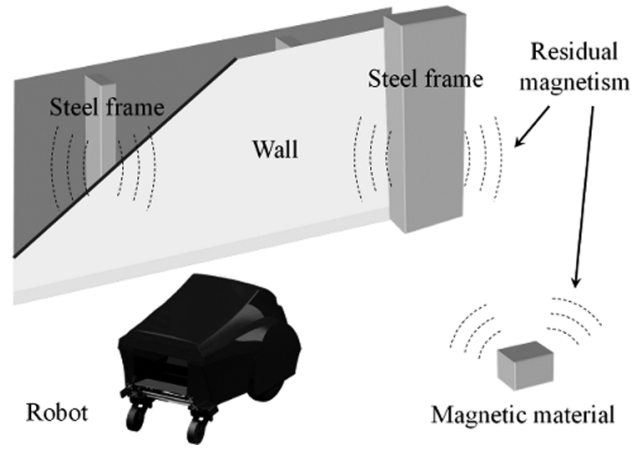

Fig. 1 Localization method using residual magnetism

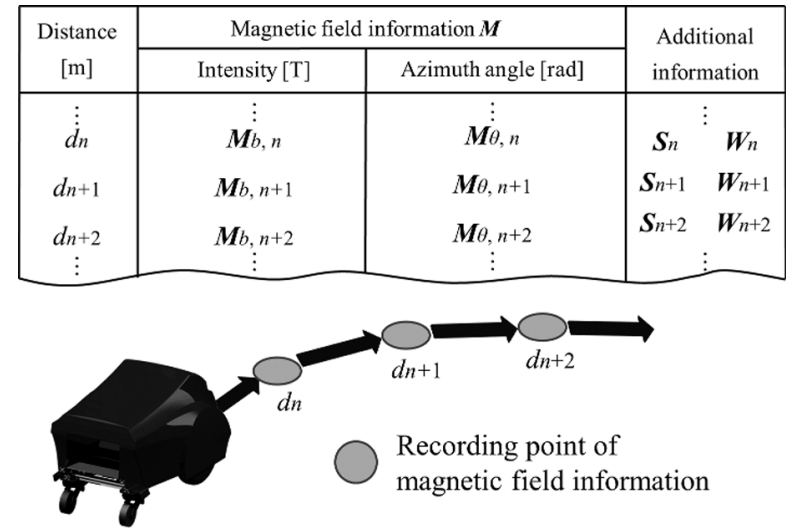

Fig. 2 Implementation example of a magnetic field map

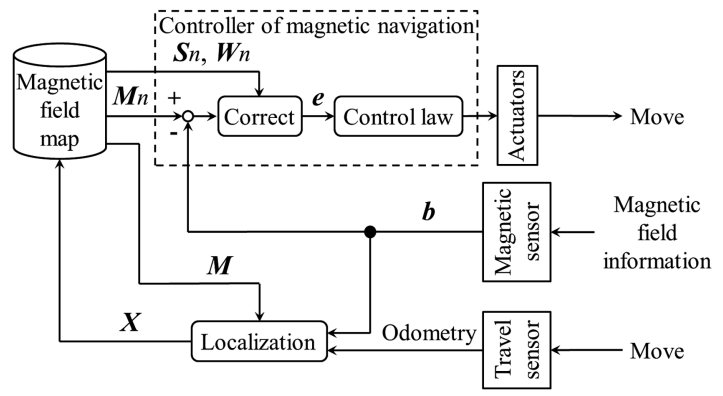

Fig. 3 Control algorithm of the magnetic navigation method

磁場の性質を把握し, 磁場をロボットの制御に対して有効に利 用できるようにする。

2.3 ナビゲーションアルゴリズム

Fig. 3 には，磁気ナビゲーション法の制御アルゴリズム図を 示す，磁気ナビゲーション法は，磁場マップ，位置推定モジュー ルそしてコントローラから構成される，磁場マップは，自律走 行を行う事前に作成しておく，前節で述べたように，磁場マップ には経路情報に対応した磁場情報と付加情報が記録されている.

Fig. 4 には, 磁場の乱れを利用した位置推定法の概略図を示 す. 走行距離に対応して磁場強度を記録することで，経路上に おける磁場の変化を識別できる。位置推定モジュールにおいて, 磁場情報 $M$ と磁気センサの計測值 $\boldsymbol{b}$ を利用してロボットの状 態 $\boldsymbol{X}$ を修正する。なお本研究では, ロボットの状態を走行距離 dのみで表すこととしている. 


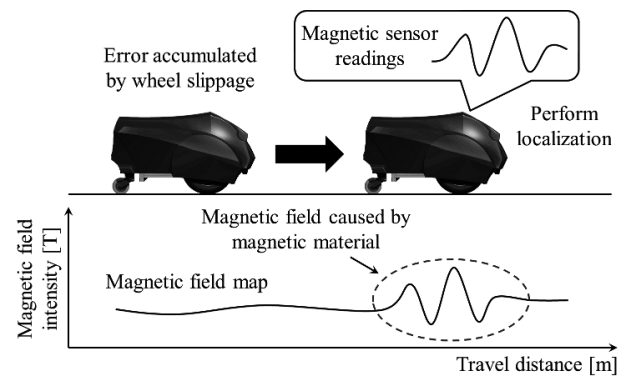

Fig. 4 Localization using variation of magnetic field intensity based on a magnetic field map

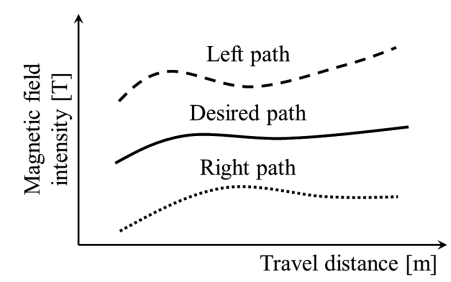

Fig. 5 Differential of magnetic field intensity on a path

しかし走行距離の修正のみでは, 経路に対する横方向の誤差 が累積する，そこでこの誤差を修正するために，走行経路の左 右の磁場強度 ${ }^{l} \boldsymbol{M}_{b},{ }^{r} \boldsymbol{M}_{b}$ を利用する，磁場の乱れが存在する 区間では, Fig. 5 に示すように, 経路の左右によって磁場強度 が変わる区間がある。このような区間では，現在計測している 磁場強度と走行経路上の磁場強度が同じになるようにロボット を制御することで, 走行経路にロボットを近づけることができ る.このような, 横方向誤差修正を行うことができる磁場の乱 れが存在する区間を識別するために識別情報 $\boldsymbol{S}$ を利用する。こ の詳細については 4.2 節で述べる.

コントローラでは，ロボットの現在位置に対応した磁場マッ プ上の磁場情報 $\boldsymbol{M}_{n}$ と磁気センサの計測值 $\boldsymbol{b}$ の差分を求め, こ れを零にするような制御を行うことを基本としている.しかし， 磁場が乱れた地点などでこのような制御を行った場合，ロボッ トが蛇行することがある，これを防ぐために，付加情報 $\boldsymbol{S}_{n}$ と $\boldsymbol{W}_{n}$ を利用して求めた差分を修正することで, 制御に利用する 偏差 $e$ を求める. 最終的に, 求めた偏差 $\boldsymbol{e}$ の各值が零になるよ うにロボットの姿勢を制御することで姿勢修正を行う。この詳 細については 4.4 節で述べる.

\section{3. 磁場の実験的解析}

\section{1 電子機器が磁気センサに及ぼす影響}

磁気センサは環境だけでなく, ロボットに搭載された電子機 器からも影響を受ける。 この影響は, 磁気ナビゲーション法に おける自己位置推定やコントローラの部分に顕著に現れ, 指定 経路の追従を困難にさせる。 これを回避するためには, 磁気セ ンサを電子機器から離さなければならない.しかし, ロボット のサイズには制限があり，確保できる距離には限界がある。そ こで，ロボットに搭載される代表的な電子機器をいくつか選び, その影響がどれほどあるかを検証することとした，本研究では， モータ,バッテリおよび $\mathrm{PC}$ を 2 種類ずつ調べた。モータは DC ブラシモータと DC ブラシレスモータ, バッテリはサイズの異

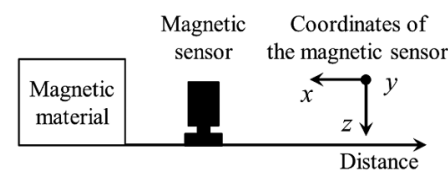

Fig. 6 Measurement shceme of influence from a electric device
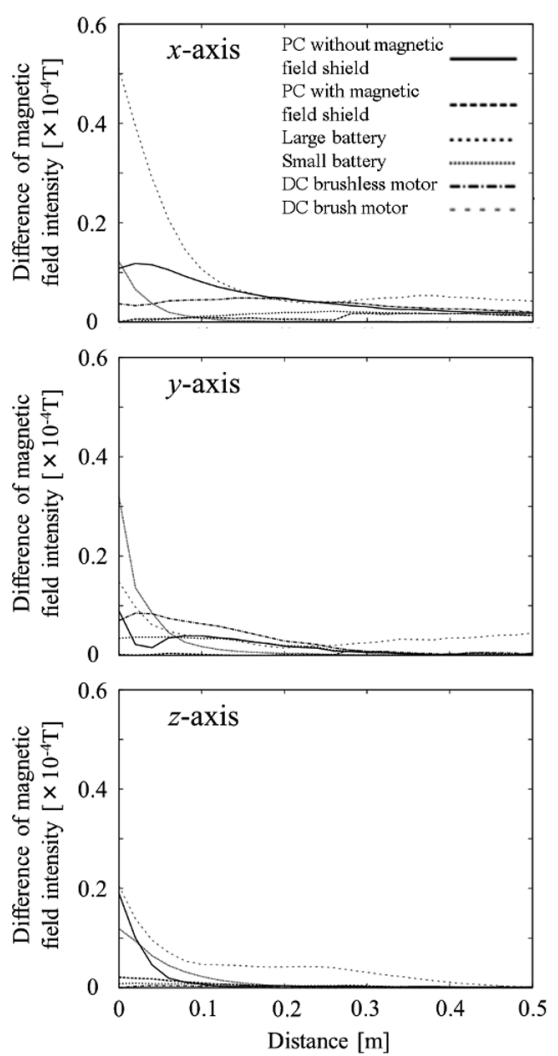

Fig. 7 Investigation result on influence from electric devices

なるもの, $\mathrm{PC}$ は磁界シールドがあるものとないものをそれぞれ 調べた。またそれぞれの検証では，モー夕なら回転時など，そ れぞれの機器が稼働している状態で行った.

電子機器の影響の調べ方の概略図を Fig. 6 に示す. まず, 周 囲に機器がない状態で磁気センサを用いて磁場強度を計測する。 そして機器を配置した後, 機器とセンサの距離を変化させなが ら再び磁場強度を測定していき, 機器がない状態との差分を計測 していくこととした，なお本検証で利用する磁気センサ（3DMDH）は， 3 軸の磁場強度を計測でき，これを用いてヨー，ロー ルおよびピッチ軸回りの磁場方位を計測できるものである。各 軸回りの磁場方位はそれぞれの軸の磁場強度から算出されてい るため, 本検証では各軸の磁場強度の影響のみを検証すること とした，磁気センサに抢ける各軸の方向は，七ンサの前後方向 を $x$ 軸, 左右を $y$ 軸, 上下を $z$ 軸としている. また本検証で は， 1 測定につき $10[\mathrm{~Hz}]$ で $5[\mathrm{~s}]$ 測定を行い, 最も変化が大き いときの值を記録することとした。

影響を調べた結果を Fig. 7 に示す，同じ種類の電子機器でも 影響の現れ方に差があることが見てとれる，また，影響の少な い機器であれば，距離を $10[\mathrm{~cm}]$ 程確保するだけで影響がほと んどなくなることが分かる，すなわち，これらのことに留意す 


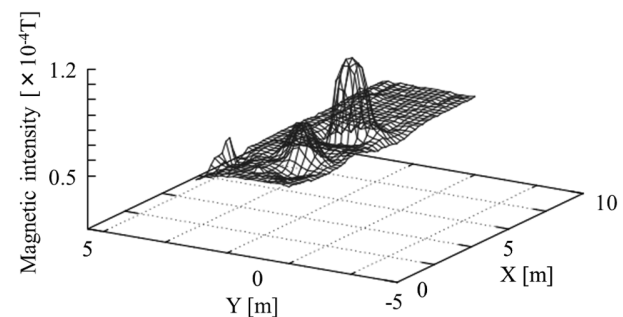

Fig. 8 Distribution of magnetic field intensity around magnetic materials

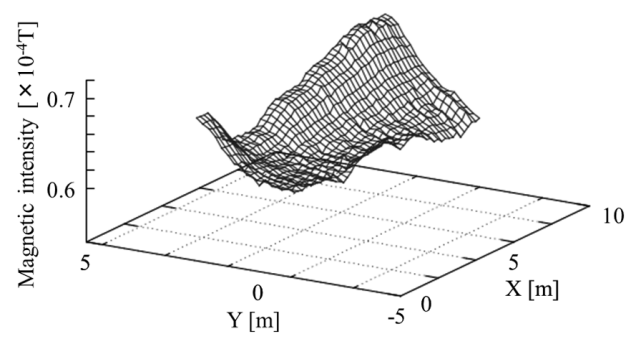

Fig. 9 Distribution of magnetic field intensity next to magnetic materials

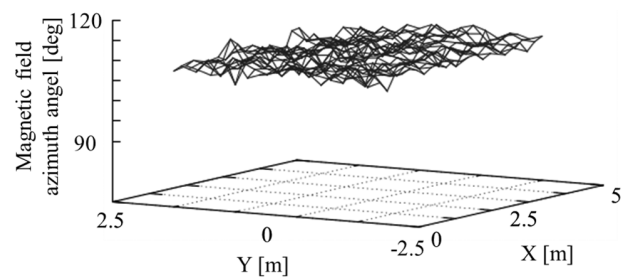

Fig. 10 Magnetic field azimuth angle on an area in stable magnetic field

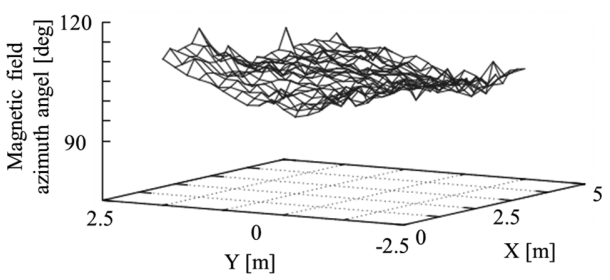

Fig. 11 Magnetic field azimuth angle on an area in unstable magnetic field

れば，ロボットに搭載された磁気センサでも，機器の影響を受 けずに環境磁場を計測できることが分かった。

\section{2 磁場の乱れの目印としての利用}

Fig. 8 には, 磁性体の影響を強く受けた区間の磁場強度の計 測例を示す，なおこの計測例では，X 軸方向をロボットの進行 方向としている. またこの計測結果は, 単一の磁気センサを用 いて各地点の值を計測して得られた結果であり, 計測の間隔は $20[\mathrm{~cm}]$ とした. 以下に示す Fig. 9, Fig. 10 执よびFig. 11 の 結果も同様に計測したものである。

Fig. 8 に示す結果が得られた地点（Fig. 14 の A 地点）は幅 約 $4[\mathrm{~m}]$ の歩道であり, 地下に排水管が埋設されている. 排水 管は, X が約 $2[\mathrm{~m}]$ と $5[\mathrm{~m}]$ の 2 箇所にあり, Y 方向に水平に 埋設されている. 磁気センサと排水管との距離は $20[\mathrm{~cm}]$ 以上 ある. Fig. 8 に示す計測例は, $z$ 軸（磁気センサの上下）方向の
磁場強度である. 排水管は地下に埋設されており, この地点で は $z$ 軸方向に対して大きな影響が現れる，そのため， $z$ 軸方向 の変化が最も目印として利用しやすい特徵的な変化となる。も ち万ん, 磁性体が磁気センサの $x$ 軸, または $y$ 軸方向に存在 していれば，その軸方向の磁場強度が特徴的に変化することに なる。

Fig. 9 には, 走行経路の横方向に磁性体が存在する区間の磁 場強度の計測例を示す。この地点（Fig. 14 の B 地点）も幅約 $4[\mathrm{~m}]$ の歩道であり, 約 $5[\mathrm{~m}]$ 離れた道の横にある建物内の磁性 体の影響を受けている。 この磁場強度も磁気センサの $z$ 軸方向 のものである. 走行経路の横方向（Y 軸方向）に対して, 磁場強 度が傾斜していることが磼認できる。 な㧍この地点の左右方向 の磁場強度は, Fig. 8 に示すような特徵的な変化を示している.

これらの計測結果から，まず，環境中に存在する磁性体は，口 ボットに搭載される電子機器よりも大きな影響を及ぼすことが 分かった，すなわち，ロボットに搭載した磁気センサでも，こ れらの影響を目印として検知できる。 そして，上述した二つの 磁場の乱れは，それぞれ異なる利用ができる．前者は進行方向 （X 軸方向）に対して特徴的な変化を示すため, 進行方向の位置 推定を行うために利用できる。一方後者は，進行方向に対して 横方向に特徵的な変化を示しているため, 進行方向に対する横 方向の位置推定を行うのに利用できる。これらの位置推定が行 えれば，ロボットをナビゲーションすることができる。これら のことから，磁場の乱れを利用してロボットの位置推定ができ ることが分かった.

さらにこれらの計測結果から, 計測間隔が $20[\mathrm{~cm}]$ でも十分 に磁場の乱れを検知できていることが確認できる。つまり，磁 場マップのデー夕記録の分解能は $20[\mathrm{~cm}]$ 以下であれば十分で あることが分かった。 また，磁気ナビゲーション法によって発 生する経路に対する横方向の誤差は, 最大でも $1[\mathrm{~m}]$ 程度であ る [2] [3]. このことと Fig. 9 の結果から, Fig. 5 に示す左右の 磁場強度を取得する際には, 走行経路より約 $1[\mathrm{~m}]$ 離れた地点 のデータを記録するのがよいといえる。

\section{3 磁場方位を用いた姿勢修正}

Fig. 10 には，磁性体の影響を受けていない区間における磁場 方位の計測例を示す。なお本検証では, 磁気センサのヨー軸回 りの磁場方位を計測している。 この地点（Fig.14の A 地点の 約 $30[\mathrm{~m}]$ 右）は，周囲には何も存在しない開けた区間となって いる，この区間では，ほとんどの地点で同程度の值が計測され ていることが分かる，そのため，どの地点の方位を比較しても 差はほとんど零となる。 つまり, 自律走行時に計測している磁 場方位と，事前に登録した磁場方位の差分が零になるように制 御すれば, どの地点においてもロボットの姿勢を一意に修正で きる，このことから，磁場が安定している区間では，磁場方位 を用いた姿勢修正が有用であることが分かった。

Fig. 11 には，磁性体の影響を受けている区間における磁場方 位の計測例を示す.この地点（Fig. 14 の B 地点）の磁場方位 の值は, 変化が大きいことが分かる. この地点に扔いて, 前述 したような磁場方位の比較による制御を行った場合，参照する 事前登録データが少しでも異なった場合， ロボットの姿勢修正 が失敗することになる。つまりこの地点では, 磁場方位を利用 
した姿勢修正を行うことが困難であることが分かった。しかし この地点では, 多くの場合 Fig. 8 や Fig. 9 に示すような磁場の 乱れが存在する。そそのため, 位置推定に利用できる磁場の乱れ が存在する場合が多い.

\section{4. 磁気ナビゲーション法の実装}

\section{1 ハードウェア構成}

前章において, 磁気センサが電子機器から受ける影響の性質 を示した。この結果から, ロボットを構成する電子機器を選定 する際に留意しなければいけないことは, 機器の種類により影 響に差があることと, 機器と磁気センサ間の距離を十分に確保 することである，そこで本研究では，まず機器をロボットの大 きさを考慮して選定し, その後, センサに及ぼす影響をそれぞ れ検証し，影響がなくなる距離を確保することとした。

Fig. 12 には, 本研究で開発したロボットを示す．またFig. 13 には，ロボットの断面図と代表的な電子部品の配置を示す，本 ロボットは前輪を両輪独立制御方式としており, その場旋回を 行うことができる. 駆動軸中心の地面から $50[\mathrm{~cm}]$ の高さに 3 軸磁気センサ（3DM-DH）を 1 台搭載した。磁気センサの各軸 の方向は, ロボットの進行方向を $x$ 軸, その $90[\mathrm{deg}]$ 右方向を $y$ 軸, そして地面方向を $z$ 軸とした。磁気センサの設置場所は, すべての電子機器から $20[\mathrm{~cm}]$ 以上の距離を確保している。 ま た，ロボット前方に LIDAR（UTM-30LX）を搭載し，これを 衝突回避のみに利用することとした。

\section{2 磁場マップの構築}

磁気ナビゲーション法では, 事前に走行経路でロボットを手 動で走行させて磁場マップを構築する. 磁場マップには, 走行 経路上の磁場情報 $M_{b}$ と $M_{\theta}$, 付加情報 $S$ と $W$ をそれぞれ 走行距離に対応して記録した。磁場マップの構築の際には, 口 ボットを約 $0.6[\mathrm{~m} / \mathrm{s}]$ で走行させ, $10[\mathrm{~Hz}]$ で磁場の観測を行う こととした，また，磁場マップにおける情報の記録間隔は，前 章での計測結果を基にして $10[\mathrm{~cm}]$ とした. $10[\mathrm{~cm}]$ の間隔で複 数回の観測が行われた際には，その平均值を記録していく。ま
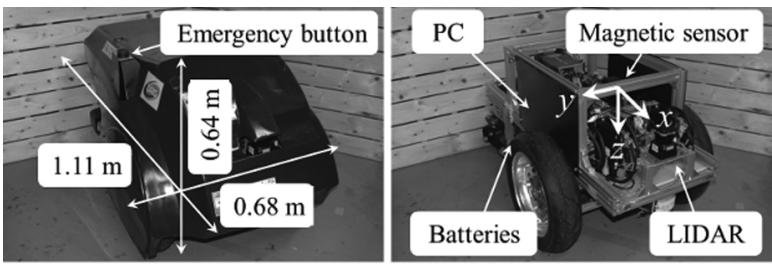

Fig. 12 View of a robot with the armor and without the armor

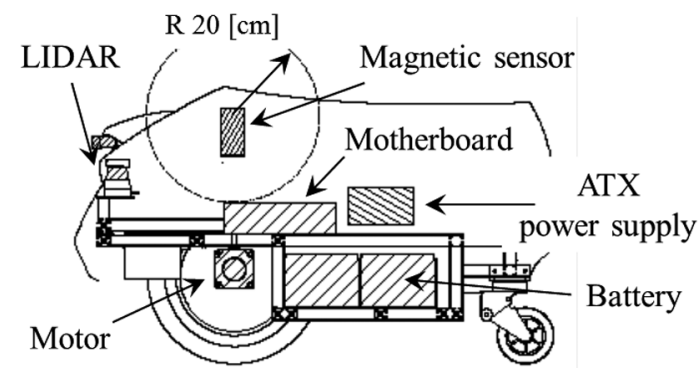

Fig. 13 A sectioned drawing of the robot
た $\boldsymbol{M}_{b, n}$ には 3 軸方向の磁場強度 $m_{x, n}, m_{y, n}, m_{z, n}, \boldsymbol{M}_{\theta}$ に はヨー軸回りの磁場方位 $m_{\theta, n}$ を記録した。 また識別情報 $\boldsymbol{S}_{n}$ には，それぞれ 3 軸方向の磁場の乱れを識別するために $s_{x, n}$, $s_{y, n}, s_{z, n}$ を記録した. さらに, 重み情報 $\boldsymbol{W}_{n}$ には, 3 軸方向 の磁場強度とヨー軸回りの磁場方位を用いた修正量を決定する ために $w_{x, n}, w_{y, n}, w_{z, n}, w_{\theta, n}$ をそれぞれ記録した。

識別情報 $\boldsymbol{S}_{n}$ は, Fig. 5 に示すような磁場の乱れを有する区間 を識別するために利用する。，そのため, 経路上の磁場強度 $M_{b, n}$ および左右の経路の磁場強度 ${ }^{l} \boldsymbol{M}_{b, n},{ }^{l} \boldsymbol{M}_{b, n}$ を用いて, 以下の 式に従い決定した.

$$
s_{k, n}= \begin{cases}1 & \left({ }^{l} m_{k, n}+m_{t}>m_{k, n}>^{r} m_{k, n}-m_{t}\right) \\ -1 & \left({ }^{l} m_{k, n}-m_{t}<m_{k, n}<{ }^{r} m_{k, n}+m_{t}\right) \\ 0 & \text { (otherwise) }\end{cases}
$$

ここで $k$ は, $x, y, z$ の添字をそれぞれ表し $m_{t}$ は任意の闇 值である. 本研究では $m_{t}$ は, Fig. 9 の計測結果も参考にして $0.01\left[\times 10^{-4} \mathrm{~T}\right]$ とした。 なお, 左右の磁場情報の取得も, ロボッ 卜を手動走行させることで行う

重み情報 $\boldsymbol{W}_{n}$ は, 実際に走行経路でロボットを走行させ，そ のときのロボットの動作を基にして実験的に決定することとし た，具体的には, 初期は一意に重みを設定しておき, 走行させ た際にロボットが蛇行するようであれば重みを下げていくこと で決定することとした。

\section{3 走行距離の推定}

ロボットには自律走行を行う事前に, Fig. 8 に示すような変 化がある地点と, その変化の最大值を教示しておく、ロボット

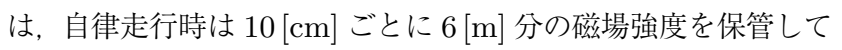
いく.な扮自律走行の際も，ロボットは約 $0.6[\mathrm{~m} / \mathrm{s}]$ で走行し, $10[\mathrm{~Hz}]$ で磁場の観測を行っていく，そして，目印となる変化が 存在する地点を $3[\mathrm{~m}]$ 過ざた際に, 保管した磁場強度の最大值 を求め, これとあらかじめ教示した最大值の差分が一定以下で あれば, 目印となる磁場の乱れを計測したとする。 そして, 観 測した磁場の乱れの位置があうように，走行距離の修正を行う こととした，磁場マップのデータは $10[\mathrm{~cm}]$ ごとに記録されて いるため, 距離の修正は $10[\mathrm{~cm}]$ 単位で行われることとなる.

\section{4 制御手法}

本研究で実装した磁気ナビゲーション法に扔ける走行制御で は，まず，現在のロボットの走行距離に対応した磁場マップの 磁場情報 $\boldsymbol{M}_{n}$, 付加情報 $\boldsymbol{S}_{n}$ と $\boldsymbol{W}_{n}$, 抢よび磁気センサの計測 值 $\boldsymbol{b}$ を用いて, 制御に利用する偏差 $\boldsymbol{e}$ を以下のように定めた。

$$
\boldsymbol{e}=\left[\begin{array}{c}
s_{x, n} w_{x, n}\left(m_{x, n}-b_{x}\right) \\
s_{y, n} w_{y, n}\left(m_{y, n}-b_{y}\right) \\
s_{z, n} w_{z, n}\left(m_{z, n}-b_{z}\right) \\
w_{\theta, n}\left(m_{\theta}-b_{\theta}\right)
\end{array}\right]
$$

ここで, $b_{x}, b_{y}, b_{z}$ は磁気センサが計測する 3 軸の磁場強度で あり, $b_{\theta}$ は磁場方位である. そして偏差 $\boldsymbol{e}$ の各值が零になるよ うに，ロボットの角速度を PD 制御することで姿勢を修正する こととした 
磁場マップには, 磁場情報としては走行経路上の情報しか記 録されていない.そのため, 障害物回避などにより経路から逸 れた際には，参照する磁場情報がなくなることとなる。これを 防ぐために付加情報を利用している，付加情報は，周囲の磁場 の性質を表すパラメータであり，これを用いることで経路周辺 の磁場を大まかであるが把握することができる，例えば，識別情 報 $\boldsymbol{S}_{n}$ がすべて零となるような地点は磁場が安定しており, 磁 場方位を用いて姿勢を修正すれば姿勢を一意に修正できる。こ れは，前章において磁場解析を行った結果からも明らかである。 また， $\boldsymbol{S}_{n}$ の各值が非零であれば，横方向の誤差を修正するよ うな姿勢修正が行われることになる。このように，付加情報を 利用することで，走行経路上の磁場情報しか持たないとしても， ロボットの姿勢修正を効果的に行うことが可能である.

\section{5. 走 行 実 験}

\section{1 実験環境}

Fig. 14 に実験環境を示す. 図中の $\mathrm{A} \sim \mathrm{E}$ 地点は, Fig. 8 に示 すような走行距離の修正を行うことが可能な磁場の乱れが見ら れる地点である。また，図中の右下の点線四角で囲まれた区間 は，磁場が時間変化する区間であり，正しい磁場方位を計測す ることが難しい，それ以外の区間では，磁場方位は概ね安定し て計測できる，経路に対する横方向の誤差を修正できるような 区間は，ところどころに点在している。図中の B 地点にのみ, 約 $15[\mathrm{~m}]$ 連続して横方向の誤差を修正できる区間がある.

\section{2 走行実験}

本実験では，実装した磁気ナビゲーション法によってロボット が自律走行を行うことが可能かを確認するため，まず，Fig. 14 に示す経路を連続で周回走行させた. Fig. 15 には, 周回走行 した際の 4 周分の走行軌跡を示す。すべての周回において同様 の経路を走行し，安定した自律走行が行えることを確認した． また自律走行中の経路から横方向のずれは，目測ではあるが約

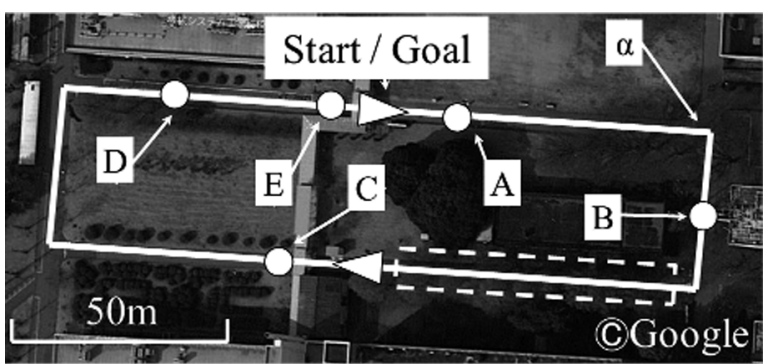

Fig. 14 Experimental course

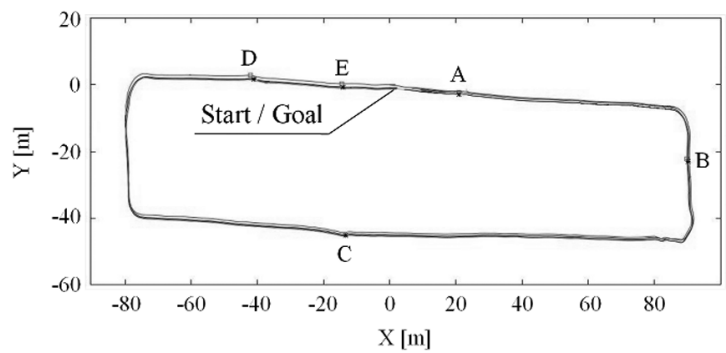

Fig. 15 Trajectories by the magnetic navigation method $1[\mathrm{~m}]$ 以内であった。道路幅 $4[\mathrm{~m}]$ の本実験環境においては，十 分な位置精度で走行することが可能であった。

走行距離修正の性能評価のために, Fig. 14 の $\mathrm{A} \sim \mathrm{E}$ 地点にお いて修正がうまく行われたか，また修正が行われた際には修正 前の走行距離を記録し, どの程度の修正が可能であるかを検証 した. Table 1 にはA〜E 地点における各周回での走行距離修 正の結果をまとめた。位置修正に失敗した地点には「メ」を記 している。この表より, まれに位置修正に失敗するものの, 最 大誤差 $1.7[\mathrm{~m}]$ の走行距離修正が行えることが分かった．また， $100[\mathrm{~m}]$ に 1,2 箇所の目印となる磁場の乱れが存在すれば, 本 手法による自律走行が可能であることも分かった.

Fig. 16 には，本実験で用いた磁場マップをグラフ化した一 部を示す。これは, Fig. 14 に示すスタート地点から $\alpha$ までの ものである. A 地点には特徴的な磁場の乱れが見られ, これを 用いて走行距離の修正を行うことができた。 またこの地点の周 辺の磁場方位は, 場所による変化が大きかっため, 姿勢修正に 利用する重み $w_{\theta}$ を他より小さくした，さらに，付加情報であ る $\boldsymbol{S}$ と $\boldsymbol{W}$ の各軸成分の積は, 横方向の誤差修正を行うための 指標となる。 この值が非零の地点では誤差修正が行われた.

Table 1 Localization result in the navigation experiment

\begin{tabular}{|c|c|c|c|c|c|}
\hline Position & A [m] & B [m] & C [m] & D [m] & E [m] \\
\hline \hline Magnetic field map & 23.2 & 94.2 & 220.3 & 346.8 & 389.1 \\
\hline 1st Run & 23.3 & 94.9 & 221.2 & 347.8 & $\times$ \\
\hline 2nd Run & 22.1 & 93.4 & $\times$ & 347.9 & 389.3 \\
\hline 3th Run & 21.5 & 93.8 & 221.1 & 347.4 & 389.6 \\
\hline 4th Run & 21.7 & 93.8 & $\times$ & 346.6 & 389.3 \\
\hline \hline Max error & 1.7 & 0.8 & 0.9 & 1.1 & 0.5 \\
\hline
\end{tabular}

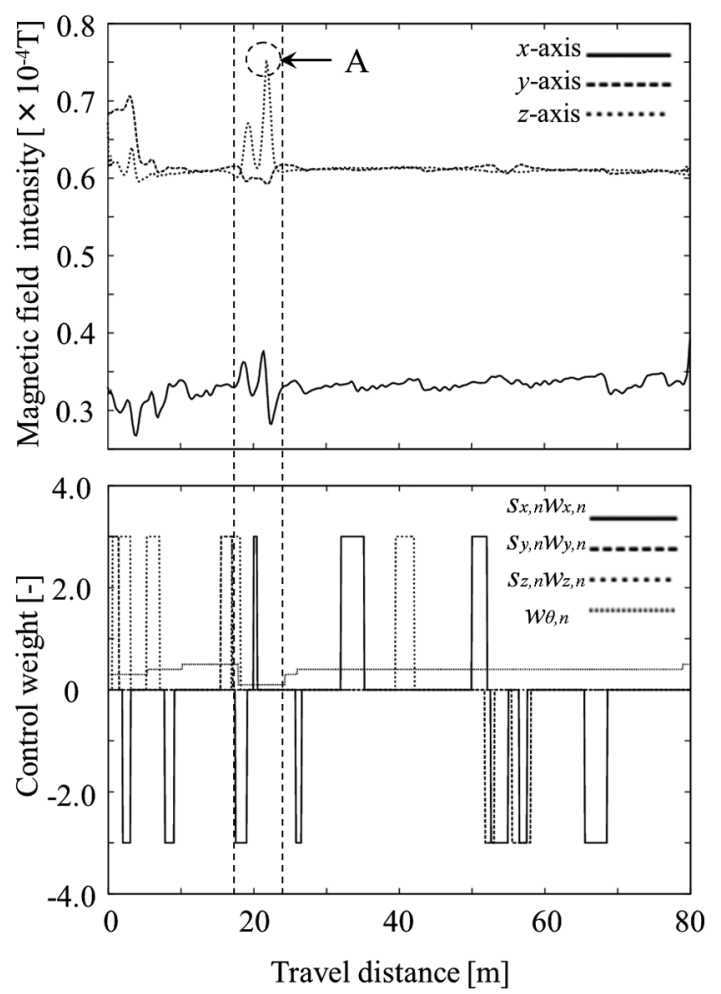

Fig. 16 Data of the magnetic map in the experiment 


\section{3 考察}

Table 1 より，C， E 地点では磁場の変動を目印とした走行 距離修正に失敗するケースがあった。この地点の磁場の乱れは, A 地点などと比べるとわずかに小さなものであった，そのため， 走行経路からずれると, 磁場の乱れを計測することができず, 距 離修正に失敗したと考えられる. しかし, 他の地点でも磁場の 乱れが見られた際には距離修正を行うことができ，結果として 周回走行を達成できた。このことから, 磁気ナビゲーション法 による自律走行では, 常に高い精度の位置推定を必要としない ということがいえる。これは，磁場マップを利用した姿勢修正 の利点である. 磁場マップには走行経路周辺の磁場の性質が記 されているため, 常に環境磁場を有効に利用した姿勢修正を行 うことができる。このため，多少位置推定に失敗したとしても， これが直結して即座に自律走行に失敗することはない.このこ とは, 近年よく利用されている Monte Carlo Localization [10] やスキャンマッチング法 [11] と比較すると, 磁気ナビゲーショ ン法の大きな利点であるといえる。また, 磁気ナビゲーション 法はこれらの手法と比較すると, そもそも自己位置推定に利用 する情報が異なるため，これらの手法により走行できない区間 での走行も行うことができる. 実際, 先に示した実験では, 磁 気ナビゲーション法により，周囲が開けた区間においても容易 に自律走行を達成できた，以上のことから，磁気ナビゲーショ ン法は多様な環境での利用が可能であるといえ, 有用な手法で あるといえる

本論文中で述べたように，環境中のすべての磁場を計測し地 図化することは困難である，先に示した実験においても，すべ ての磁場を計測することはしていない. しかし，本研究によっ て明らかとなった磁場の性質を踏まえて磁気ナビゲーション法 を実装することで, 磁場を効果的に利用し, 実環境の自律走行 を達成できた。このことからも本研究結果は, 磁場の性質を明 らかにした結果であるといえる。

\section{6. おわりに}

本論文では, 磁気ナビゲーション法を効果的に実装するため に, ロボットに搭載される機器が周囲に及ぼす影響を検証した。 そして，ロボットに搭載した磁気センサが機器から影響を受け ずに，環境磁場を計測できることを示した，また，環境磁場を 測定して実験的に解析することで, 目印となり得る磁場の乱れ の存在およびその傾向が明らかになった，そしてこれらの知見
に基づき磁気ナビゲーション法を実装し, 実環境中で安定した 自律走行が可能であることを示した.

磁場の乱れ扱う本手法と, 周辺環境の幾何的な形状を測定す る自己位置推定法 [10] [11] とは，明らかに扱う情報が異なる. より安定した自律走行を実現するためには，これらを互いに補 間し合うような組み合わせが有力である. 今後, 磁気ナビゲー ション法をべースとし, 異なる情報を用いた自己位置推定法を 組み合わせたナビゲーション法を開発する.

謝 辞 本研究は，科研費 25420210 の支援を受けた。また， 筆者は斎藤裕氏から援助をいただいた。ささらに, 本研究におけ る環境磁場計測では, 当研究室の中田未央氏および山内健司氏 から多大な協力を得た。ここに謝意を表す。

\section{参 考 文 献}

[1] S.Y. Lee, et al.: "Navigation of automated guided vehicles using magnet spot guidance method," Robotics and Computerinterrated Manufacturing, vol.28, no.3, pp.425-436, 2012.

[2] S.A. Rahok, et al.: "Navigation Using an Environmental Magnetic Field for Outdoor Autonomous Mobile Robot," Advanced Robotics, vol.25, Nos13-14, pp.1751-1771, 2011.

[ 3 ] S.A. Rahok, 他：“環境磁場に基づいた移動ロボットの自律走行”, 計 測自動制御学会論文集, vol.47, no.3, pp.166-172, 2011.

[4] 渡辺敦志, 他: “方位検出と交差点認識を用いた道なり走行ベースの屋 外自律ナビゲーション”, 日本ロボット学会誌, vol.30, no.3, pp.271279, 2012.

[ 5 ] W. Kwon, et al.: "Particle Filter-based Heading Estimation using Magnetic Compasses for Mobile Robot Navigation," Proc. of the IEEE Int. Conf. on Robotics and Automation, pp.27052712,2006

[6] K. Ohno, et al.: "Differential GPS and odometry-based outdoor navigation of a mobile robot," Advanced Robotics, vol.18, no.6, pp.611-635, 2004.

[ 7 ] T. Yoshida, et al.: "A Sensor Platform for Outdoor Navigation Using Gyro-assisted Odometry and Roundly-swinging 3D Laser Scanner," IEEE/RSJ Int. Conf. on Intelligent Robots and Systems, pp.1414-1420, 2010.

[8] 新納敏文：“環境磁場計測法の事例調査（その 3)”, 日本建築学会大 会学術講演梗概集, pp.1021-1022, 1996.

[9] サム アン ラホック, 他：“磁気マップに基づいた屋内車輪型移動ロ ボットの自己位置認識”, ロボティクス・メカトロニクス講演会 08 , 2P2-C08, 2008.

[10] F. Dellaert, et al.: "Monte Carlo Localization for Mobile Robots," IEEE Int. Conf. on Robotics and Automation, pp.1322-1328, 1999.

[11] Y. Chen, et al.: "Object Modeling by Registration of Multiple Range Images," IEEE Int. Conf. on Robotics and Automation, pp.2724-2729, 1991. 


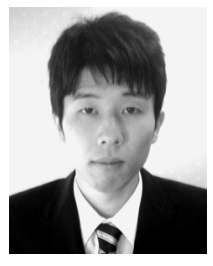

赤井直紀（Naoki Akai）

2013 年宇都宮大学大学院博士前期課程修了後, 同年 同大学博士後期課程入学, 現在に至る. 移動ロボッ トのナビゲーションに関する研究に従事. 2011, 12 および 13 年につくばチャレンジの課題を達成しつ くば市長賞を受賞。（日本ロボット学会学生会員）

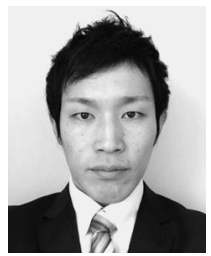

\section{片寄浩平 (Kohei Katayose)}

2013 年宇都宮大学大学院博士前期課程修了後, 同 年株式会社吉野工業所入社，現在に至る。

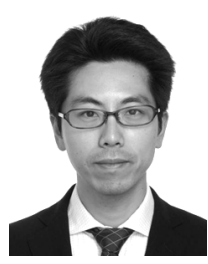

井上一道 (Kazumichi Inoue)

2000 年新潟大学理学部物理学科卒業. 2004 年 (株) エイム入社. 自動車用部品の設計開発に従事. 2008 年より宇都宮大学大学院工学研究科博士後期課程に 在籍. 感性評価とロボットのデザインの研究に従事 している.

(日本ロボット学会学生会員)

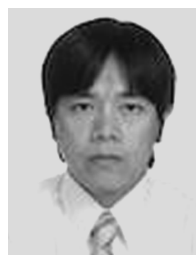

\section{Sam Ann Rahok}

2008 年宇都宮大学大学院工学研究科情報制御シス テム科学専攻修士課程修了. 2011 年同大学大学院 工学研究科博士後期課程修了. 同年同大学地域共生 研究開発センター大学院 VBL 部門研究員. 2012 年より小山工業高等専門学校電気電子創造工学科助 教. 博士 (工学)。（日本ロボット学会正会員）

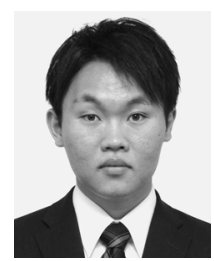

\section{島田 遼 (Ryo Shimada)}

2012 年宇都宮大学工学部機械システム工学科卒業 後, 同年同大学大学院工学研究科機械知能工学専攻 入学, 現在に至る。

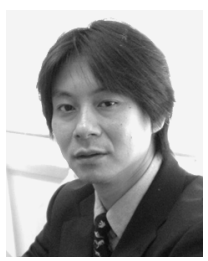

\section{尾崎功一（Koichi Ozaki）}

1996 年宇都宮大学工学部助手. 1997 年同大学講師. 2002 年同大学工学研究科助教授を経て, 現在は同 大学教授、移動ロボット，ロボット技術応用に関す る研究に従事. 博士 (工学).

（日本ロボット学会正会員） 